\title{
Poetic Language: Heidegger and Us
}

\author{
Jun Wang \\ Wuhan University
}

\begin{abstract}
Late Heidegger's thinking of language is on the way to pure language, for Heidegger tries to overcome the impurity and equipment-treating of language. The pure language shows itself as poetic language. Poetic language overcomes the impurity of everyday language and theoretic language before it reveals itself as Saying and Silence, the conversation between poetry and thought, and the possible poetic dwelling. However, Heidegger's poetic language has its limitation, which calls for our rethinking of his thinking of poetic language and language itself and makes us bring forth the contemporary nature of poetic language. In this sense, poetic language is to become the purest language or language of the very beginning. Also three sorts of languages are differentiated: language of desire, language of equipment, and language of truth (poetic language), of which poetic language is simultaneously the game of language of desire, language of equipment, and language of truth (poetic language). Poetic language in the contemporary times helps us to think about our fate in our times and urges us to build our own dwelling home.
\end{abstract}

Keywords: Heidegger, poetic language, game, contemporary nature

\section{Introduction and Question}

The whole thought of Martin Heidegger runs on the path of "The Vocation of the Matter of Thinking" (Heidegger 1998, III). This path is "being" from the world to the history, and ultimately tries to transfer the question of being into the question of language, i.e., the origin of being should be language. However, he didn’t achieve here actually; therefore, he claimed that he was just Unterwegs zur Sprache (On the Way to Language). Therefore, poetic language of Heidegger continues to go to the purer and the beginning - the language of truth. As a matter of fact, the path of Heidegger also indicated this point: Truth is the Clearing (Lichtung) in the woods where being can show itself or be unconcealed. The Clearing in the woods is a beginning place, while language is the locality of this place. Heidegger's later thought of poetic language could actually be his developed viewpoint of truth, i.e., the nature of language is truth. Thus, the path of Heidegger has called us upon: to think about the possibility of poetic language in our contemporary era.

"The contemporary era" means: the era that we are currently living in, which can be overlapped and crossed over with the modern and the post-modern but is essentially the world of our present life. But what are the differences between the world of our present life and the previous worlds? What are the differences between the world of our present life and the western worlds, e.g., the world of Martin Heidegger? Firstly, the world of our present life is different from the traditional historical world of Chinese people with the three-in-one harmony of Heaven, Earth and Humans, an ancient beautiful dream of the harmony of Heaven and Humans

Jun Wang, Ph.D., School of Philosophy, Wuhan University, China; main research fields: History of Philosophy (Heidegger), Philosophy of Art, and Aesthetics.

Acknowledgements: The paper is supported by “The Fund of China Scholarship Council” (CSC No. 201306275005) and “The Fundamental Research Funds for the Central Universities” (No. 20110330) of China. 
where Humans abided by the rules specified by Heaven and Earth of themselves; secondly, the world of our present life is different from the world of Martin Heidegger's earth, sky, divinities, and mortals where the mortals abided by the rules specified by being and the game with the participation of the divinities who were presumed as self-evident however the darkest. Our contemporary era is actually the era of "the Declining of Heaven" and "the Death of God;" that's why we expect the resurrection of Tao, truth, and wisdom. But our contemporary era can only be the world of the inter-generating of Heaven and Humans without presuming an eternal changeless historical world; therefore, this world is generated, surpassing being and turning to language; it is without the dimension of Gods and is, therefore, concise and bright. Such world of the inter-generating of Heaven and Humans is an ideal world where "poetically man dwells" as our real contemporary home. But such home is firstly only possible, and we need to build and think about it.

However, what is the relationship between poetic language and the contemporary era? In the Western society, postmodernism formed language into a theme, different from the question of being in modern thoughts and different from the traditional ontology and epistemology. In traditional Chinese philosophies, Confucius emphasized the teaching by precept and example and the cultivation by poetry as the beginning of humanity; however, Tao by Laozi is basically inexplicable but also demonstrated by the work of "Daodejing (Tao Te Ching)" which proves that language permits the being of Tao; the Zen School of Buddhism claimed "no establishment of words" while left a legacy of voluminous literatures and works, which also expressed the thoughts in the truth or poetic language that were non-vocation or anti-vocation. As a matter of fact, the wisdom of the three main schools of traditional Chinese philosophies of Confucianism, Taoism, and Zen was actually the beginning language. But, instead of discussing the question of language in the postmodern West world or ancient China, we point out here that poetic language should be contemporary, for contemporaneity is the possibility of poetic language.

Martin Heidegger defined the nature of language as the pure language or poetic language (Heidegger 1999, 194), which overcomes the impurities of daily language and theoretical language and shows itself as Saying and Silence, the conversation between poetry and thought and the poetic dwelling. But, poetic language doesn't become the beginning language after differentiating itself from daily language and theoretical language; therefore it is not pure yet; because, for Heidegger, poetry is receptivity but mainly receptivity for being. Also, poetic language is mainly limited within the literary language-as the discourse of the poets in the world without any differentiation from the world, because, for Heidegger, the world is original, is the nature of being while being precedes thought, which limited his thought on language within the range of the world. The game of language of the quaternary world of the earth, sky, divinities, and mortals is poetic, but this poetry depends on the monotheism and cannot hit the point of the world of our contemporary life. Poetic language opened the possibility of how "poetically man dwells;" however, the home where "poetically man dwells" points to the future rather than the present.

Therefore, our path of thought should be: for the matter of Sprachgestalt, after the differentiation of daily language and theoretical language, poetic language should also become the beginning language with the receptivity of pure language and become pure language; for the matter of discourse, poetic language should become an organism with organic integration to become the discourse of three languages of "Desire, Equipment and Truth (or Desire, Technology and Tao)” (Peng 2005, 20-22). Here, Desire is original; Truth is directing and hence the highest while Equipment can make both of them possible; therefore, Desire, Technology, and Tao discourse the three aspects of the beings and become the home of our contemporary world. 
There, the so-called becoming the beginning language is to become pure language where language becomes the self of language with the self-vocation for itself. This beginning is neither in space-time nor in logic, but it makes space-time and logic possible. The beginning language is just like Tao in the Chinese philosophy. Tao is the beginning non-being, without the signified signifier while producing one which is neither one of anything nor everything. But nonbeing is the great being, therefore Tao created one as the integration of being and non-being; and based on this, being and non-being created yin and yang and everything. Meanwhile, just as Tao of the Chinese philosophy demonstrates the three parties of nature, society and spirit and the vocations for the three of themselves so as for the formation of the three, poetic language as the beginning language also demonstrates the three factors of Desire, Equipment and Truth, and the vocations for the three of themselves so as for the formation of the three. In Taoism, the nature of Tao is dominant; while in poetic language, truth or Tao, wisdom and poetry are dominant.

But, to better express the poetic language different from that of Heidegger's, firstly the differentiation of language is required, and then the game of language.

\section{Differentiation of Language}

In the poetic language of Heidegger, the quaternary is discoursed by speech and language itself; therefore the mortals can have the possibility of poetic dwelling. However, the quaternary can differentiate from the overall beings of the metaphysical history, the creatures by God, the universes of nature and history, and the being-in-the-world of the world and the historical Earth and World; it is just the language with the vocations by the world and the history, i.e., it is not only the language of nature above all. "But the quaternary world is a world of language, if it is pointed by the language” (Peng 2000, 135). For the directions of the language, we should rethink Heidegger's thought on language and also differentiate and define the languages themselves.

The Bible says, "In the beginning was the Word, and the Word was with God, and the Word was God" (The Bible 2000, Gospel of John, Section 1 of Chapter 1). Here, that "the beginning was the Word" was that "the beginning was the Language," of course this language is not any ordinary language, but Tao, or the language of Tao- the language that was becoming the beginning language. Tao, in "Shuowen Jiezi (Analytical Dictionary of Characters)," was explained as "the path of walking” (Xu 1963, 42) where Tao was defined as the path, while the real path is the path of language. In Taodejing (Tao Te Ching), "The Tao that can be Taoed (spoken) is not the eternal Tao" (Chen 1984, 53). Here, the second "Taoed” is about speech. But whose speech? It can only be the speech of language, i.e., spoken by Tao, because Tao is essentially inexplicable. Tao nominates and calls; when the world was not nominated, it was a non-world with chaos, disorder and no name. Because of the nomination of Tao, everything was expressed, and the world became a world of cosmos. At the same time, Tao is cultivative, i.e., "Tao produces one, one produces two, two produce three, three produce myriad things” (Chen 1984, 232). However, when Tao produces everything, it doesn't demonstrate as everything but shows itself in everything.

Therefore, the language spoken by the pure language, i.e., the beginning language, is not a language of Desire or Equipment, but the language of Tao or Truth, wisdom and poetry. Tao is Truth, as the revelation of the pure language itself, as the wisdom in the vocation on Humans, i.e., on "poetically man dwells." For the matter of Sprachgestalt, it is not daily or theoretical language, but poetic language. Since Heidegger, language itself hasn't been clearly thought about as the beginning differentiation. For Heidegger, language is essentially within the vocation of the world and history and cannot acquire the language of itself and become the speech of itself. 
However, only when language itself isn't within the vocation of the world and history, could it acquire the nature of itself or become the speech of itself. Such language is a language of wisdom, as the singing of Muse, the doctrines of Christ and the speeches of citizens, as the directions in all eras in Western history. (Peng 2000, 188)

Homer listened to the singing of Muse and wrote the epic, and his speech was that Humans should become heroes. In The New Testament of the Bible, the speech of the truth of God directs Humans to become the Saint. In the recent works by Jean-Jacques Rousseau, etc., the speech directs Humans to become free citizens. However, in modern and postmodern eras, wisdom has been replaced by Technology and Desire, which is the homelessness demonstrated in an extreme form. Therefore, this requires us to differentiate the speech, i.e., the discourse by the language, so as to differentiate the three languages: the language of Desire, the language of Equipment, and the language of Truth.

The language of Desire is the original language of Humans, because as a biological, economical, and linguistic being, the biological being of human being is the first direct reality as Desire is the first distinct of Humans, as in "The desire for food and sex is part of human nature" by Confucianism. However, if the language of Desire wants to speak for itself, it needs the language of Equipment, or it needs to become the language of Equipment. In modern society of information, it shows itself as the language of Technology, i.e., information. But the Desire of human being is borderless, as in the Chinese saying that "desire is like a valley that can never be filled.” Therefore, the extremity of the language of Desire is the desire of Desire. That's why application of the language of Equipment, its monopoly and domination are everywhere. The language of Equipment led by the language of Desire is a computing language, which is the origin of the structural nature of the modern technologies in Heidegger's thought.

However, the language of Equipment and the language of Desire cannot reach the real nature of the language itself. The nature of language is demonstrated as the language of its nature, i.e., the language of Truth. The meaning of language is not only about the spoken Desire, the spoken Equipment, but rather about the spoken Truth, i.e., the language of Truth is used to differentiate and define the language of Desire and the language of Equipment. Different from the language of Desire and the language of Equipment, the language of Truth is the beginning language. Therefore, the differentiation of the three languages is the separation of the languages from itself, i.e., the cleansing of impure language and the preserving of the pure language. The language of Desire is the direct or indirect demonstration of Desire; the language of Technology expresses, communicates, and computes; and the language of Truth teaches and directs. Here, what is mean to be thought about firstly is not the narration, neither poetic language in the sense of Heidegger's thought, but Tao itself. Tao gives speeches and directions. The language of Truth is the real pure language, i.e., the language itself is Tao, wisdom, and poetic language, differentiated from poetic language of Heidegger. Its vocation lies in the differentiation of the language of Desire and the language of Equipment, and is self-negative and self-generating. As the three aspects of nature, society and spirit of Tao constitute the integration of the beings, Desire, Technology, and Truth also speak the integration of the discourse of language.

In the view of Heidegger, the Sprachgestalt can be divided into non-poetic languages (daily and theoretical languages) and poetic language. Poetic language overcomes the impurities of the non-poetic languages and therefore, directs to the language of pure speeches. However, poetic language of our contemporary era is the real beginning language, and hence, is the language of Truth preceding thought and being. But, what is the connection between poetic language and the languages of Desire, Equipment and Truth? The answer is that the former is the integration of the language, while the latter is the differentiation of the language. 
For the aspect of the "dwelling" or the being of human being, Karl Marx criticized the alienation of human being by industrial social capital, and Heidegger thought about the homelessness in the technological era. In our contemporary era, the non-poetic dwelling of man is given new characteristics, which are the globalization, informatization, and speedup of world economy with the rapid development of sciences and technologies, and that human beings are now facing a dilemma with the added value of the material world and the devaluation of the human world. In certain period of China, in the process of modernization, in the journey centered by economic construction, the pursuit of materials with the modernization and diversification of technologies become the best means for the satisfaction of desires and hedonism. While the satisfaction or the dissatisfaction of the desires can lead to boredom or the nothingness of human. People lose faiths and the spiritual prop, and our societies are filled with nihilism, technologism, and hedonism. Meanwhile, the consumerism of this era promotes and deepens such alienation and leads to the overall alienation, and a series of ecologic, social, and human crises, i.e., the disharmony between the nature and human being, the society and human being, and the spirits and the human being. Such alienation and disharmony are even worse than the homelessness and non-poetic dwelling in the era of Heidegger.

The mission of contemporary poetic language is how to define the language of Desire and the language of Equipment with the language of Truth, so as to differentiate, to select and to decide; how to meditate on and overcome nihilism, technologism, and hedonism; how to improve the ecologic harmony, the social harmony and the spirit harmony. Here, poetic language reaches the beginning language, i.e., the pure language or the language of Truth; also, poetic language is not limited within the literary languages, but the organic integration of the three languages of Desire, Technology, and Truth, and shows itself as the demonstration of their game. Only by this, could contemporary poetic language help us think about our fate in our contemporary era, and urge us to build our contemporary home.

\section{Game of Language}

But, how does the contemporary nature of poetic language form? Can it help us think about our fate in our contemporary era, and urge us to build our contemporary home?

Amongst the three languages of Desire, Equipment, and Truth, the language of Truth seems to be the highest form, but only seems to be. The language of Truth obviously is capable of being the highest form of languages; however, in this case, it will become the monopoly and didactic language leading to radicalism and even fallacies. The language of Desire of course wants to act as the highest form of languages, which is determined by its nature of desire. The language of Equipment will try to emphasize its highest position because it is the basis of the other two to realize themselves. However, in this way, they will all surpass the borders of themselves and become other beings. As such, the real relationship among the three of the languages of Desire, Equipment, and Truth can only be the game without external rules which should be the basis or the principle outside the game. But this game has an internal rule that the basis should be established by the self for itself. The reason of such understanding is the rule of this game is not made by man, but generated by the game of the three languages; and, this is poetic language. The generation products of the game are harmony, freedom, and beauty or aesthetics. Thus, poetic language has neither cause nor result, or poetic language itself acts as its cause and result. Poetic language makes the game being played, showing and generating.

The relationship between poetry and game was also demonstrated in the history: The poetry in the sense of Ancient Greece was the giving of measures, which was similar to the Creation out of nothing just as the 
generation of the game; the poetry in early modern history was as the establishment of the making of the rules of the game, while the subject was the ego; and the poetry of Heidegger was to accept the measures of the game of the earth, sky, divinities, and mortals, and could be considered as the game of language itself. The contemporary poetry of our era is the generation of the game of the three languages of Desire, Technology, and Truth, as well as the rules of the game and the game itself. Heidegger believes that the nature of being or the nature of the world is a game in the form of the quaternary game of the earth, sky, divinities, and mortals. This game is the circular minicircle and is originally decyclization; is generation and meanwhile deprivation. The quaternary not only establish but also lose connections. These no doubt point directly at the nature of the game. But as abovementioned, the world of our contemporary era is a world where we live without the dimension of God, and is essentially a world of the ternary game of Desire, Technology, and Tao. The three languages of the Desire, Technology, and Tao are based on the differentiation of discourse, and their game reaches the poetic form of language. Such poetic language is the rule of the ternary game of Desire, Technology, and Tao, thus is also the demonstration of such ternary game.

The three words of Desire, Technology, and Tao express the themes of the thoughts in three different eras in Western history, i.e., the postmodern world is an era filled with the language of Desire; the modern world is the homeless era of technologies; and the ancient world is the origin of Western wisdom. In China, Desire, Technology, and Tao are also three keywords but without obvious sense of times. Desire can be proved by the counterevidence of "preserving the principle of Tao of Heaven, and exterminating the Desire of Humans" of Song-Ming Neo-Confucianism. Technology has always been considered as nonessentials in Chinese philosophy, contrary to Tao as the foundation, such as "Tao Precedes Technology” by Zhuangzi. In Chinese philosophy, Tao has been demonstrated as the Tao of society by Confucius, the Tao of nature by Taoism, and the Tao of spirit by Zen Buddhism. If the Western thoughts can be viewed as an integration, Desire, Technology, and Tao can act just as the three aspects of such integration. From a chronological view, different eras highlighted one of the three; but from the synchronical view, the game of the three exists in each era only with one as the dominant in the discourse, therefore, the games were not free games. Similarly, Chinese philosophy also includes the game of the three with an inevitable polarization of one of the three, such as the "language as the vehicle of Tao" on the relationship between language and Tao by Song-Ming Neo-Confucianism, as well as the "Desire or Lust" in Ming and Qing dynasties.

The polarization among Desire, Technology, and Tao has been existing ever since ancient times, but is the most severe in our contemporary era. This presents as three significant issues as follows: firstly, nihilism, which denies the basis and purpose of being, and is the extreme form of Tao, i.e., the absence of Tao; secondly, technologism, which technicalizes Humans and everything; and thirdly, hedonism, which makes Desire free from rules and borders (Peng 2005, 26). One outstanding example is that we are also living in a virtual world, i.e., the cyberspace in our contemporary era which is totally different from the real world. In cyberspace, everything is the phenomenon of language where internet language basically defined the mode of thinking and being in the cyberspace. The internet language is a pure game of Desire, Technology, and Tao, which can also be the demonstration of poetic language calling people to surf online for pleasure. On the other hand, it may only pretend to be poetic language so that people get self-indulgent and cannot get rid of it. In the case of the latter possibility, the internet language fully satisfies and re-activates the desire of people, leading to full technicalization and informatization of language, thought and being, and ultimately nihilism. 
As for the cyberspace, we should differentiate the border between the virtual world and the real world; what is virtual should be considered as virtual being and what's real should be considered as real being. This is to make the game being played and to let Desire, Technology, and Tao play the game with complete self-preservation instead of self-denial of each of the three, with complete respect of other beings rather than exterminating of the others. For nihilism, technologism and hedonism, it should be the same. That is, "On the one hand, any basis outside the being should be rejected, on the other hand, the basis of being itself should be established; meanwhile, on the one hand, technologies should be used to improve and enhance the means of our living, on the other hand the nature should be as nature itself and work as nature itself; at last, on the one hand, the desire should be liberated, and on the other hand, desire cannot become lust" (Peng 2005, 26). For the matter of harmony, each side of each issue should realize itself and let other being realize itself, so as for round dancing of all sides as a vibrant integration of social, ecological, and spiritual harmonies. All of these could only be achieved by playing and letting play, so as for the demonstration of poetic language. Poetic language is the speech of the language of Truth and defines the language of Desire and the language of Equipment; it is also the conversation and game among them, hence is demonstration and generation. The vocation of poetry will always self-deprive and self-generate in the game of the three languages.

Therefore, now the real question is how to let the poetic language of our contemporary sense speak itself, so as to point out the truth and to analyze the problems. To point out the truth and to analyze the problems are the paths to bring up the possibilities, because the answers lie within the questions when they are raised. This path is the path of language, or the path of Tao, i.e., poetic language, which defines the necessity, the realities and the possibilities of Humans, so that people know where they come from, how they march on the path of life and where they are heading, that is to teach people to live, to exist. As such, we as the contemporary human beings accept the measures given by poetic language so that "poetically man dwells" truly. In this way, Humans have Desire and not only Desire; Humans invent Technology but are not limited by Technology; Humans don’t possess Truth in the first place but comply with Truth. Therefore, the problem of nihilism, technologism, and hedonism and so on can be solved, so as for the harmony and a world of poetry, freedom, and beauty.

\section{Works Cited}

Chen, Guying. Interpretation and Review of Tao Te Ching of Laozi. Beijing: Zhonghua Book Company, 1984.

Heidegger, Martin. Pathmarks. Cambridge: Cambridge University Press, 1998.

---. Poetry, Language, Thought. Beijing: China Social Sciences Publishing House, 1999. 194.

Peng, Fuchun. The Problems of Philosophy and Aesthetics-An Unprincipled Criticism. Wuhan: Wuhan University Press, 2005.

---. Nichtung der Nihil—Core Questions of Heidegger's Path of Thought. Shanghai: Shanghai SDX Joint Publishing Company, 2000.

The Bible (Chinese Union Version with simplified Chinese characters and punctuations). National Committee of Three-Self Patriotic Movement of the Protestant Churches in China, China Christian Council, 2000.

Xu, Shen. Shuowen Jiezi (Analytical Dictionary of Characters). Beijing: Zhonghua Book Company, 1963. 